\title{
The effect of obesity on dyspnea, exercise capacity, walk work and workload in patients with COPD
}

\author{
Hülya ŞAHIN ${ }^{1}$ \\ ilknur NAZ ${ }^{2}$ \\ Yelda VAROL ${ }^{3}$ \\ Berna KÖMÜRCÜOĞLU ${ }^{3}$
}

${ }^{1}$ Clinic of Pulmonary Rehabilitation, Dr. Suat Seren Chest Diseases and Chest Surgery Training and Research Hospital, Izmir, Turkey

${ }^{1}$ Dr. Suat Seren Göğüs Hastalıkları ve Cerrahisi Eğitim ve Araştırma Hastanesi, Pulmoner Rehabilitasyon Kliniği, İzmir, Türkiye

${ }^{2}$ Department of Physiotherapy and Rehabilitation, Faculty of Health Sciences, Izmir Katip Celebi University, Izmir,Turkey

2 Izmir Katip Çelebi Üniversitesi Sağıık Bilimleri Fakültesi, Fizyoterapi ve Rehabilitasyon Bölümü, İzmir, Türkiye

${ }^{3}$ Clinic of Chest Diseases, Dr. Suat Seren Chest Diseases and Chest Surgery Training and Research Hospital, Izmir, Turkey

${ }^{3}$ Dr. Suat Seren Göğüs Hastalıkları ve Cerrahisi Eğitim ve Araştırma Hastanesi, Göğüs Hastalıkları Kliniği, İzmir, Türkiye

\section{SUMMARY}

The effect of obesity on dyspnea, exercise capacity, walk work and workload in patients with COPD

Introduction: COPD and obesity are major public health problems that cause mortality and morbidity all over the world. The combined of COPD and obesity is predicted to increase further in the coming years. Obesity primarily affects the pulmonary system by altering respiratory functions, exercise capacity, pulmonary gas exchange, and endurance and power of respiratory muscles. In this study, we aimed to compare the dyspnea sensation, exercise capacity, walk work and workload in obese COPD patients compared to preobese and normal overweight COPD patients.

Materials and Methods: 218 patients with COPD were included in the study. According to the WHO criteria for body mass index $(B M I)$, the patients were classified as normal-weight $\left(B M I=18.5-24.9 \mathrm{~kg} / \mathrm{m}^{2}\right)$, pre-obese $\left(B M I=25-29.9 \mathrm{~kg} / \mathrm{m}^{2}\right)$ and obese $(B M I=$ $30-39.9 \mathrm{~kg} / \mathrm{m}^{2}$ ). All patient respiratory function tests and arterial blood gas analysis were performed. The mMRC dyspnea scale was used to assess the dyspnoea of the patients. The exercise capacities of the patients were determined by the 6-min walking test. Walk work and workload were calculated based on 6 minutes walking distance. The obtained values were compared between the three groups.

Results: The $F E V_{1} / F V C$ ratio and TLCO value in pulmonary function tests are significantly higher in obese COPD patients than in other patients, while the VC value is significantly lower in patients with COPD $(p=0.001, p<0.001, p=0.01)$. Partial carbon dioxidewas significantly higher in obese COPD patients compared to other patients $(p=0.001)$. Dyspnea perceptions and walking distances did not differ significantly between groups. Walkwork and workload were significantly higher in obese COPD patients $(p<0.001, p=0.005)$.

Conclusion: Obesity causes partial changes in blood gas and pulmonary function tests of patients with COPD. At the same time, it increases walkwork and workload. Despite all these changes, it has no negative effect on dyspnea perception and exercise capacity.

Key words: Obesity, COPD, exercise capacity, workload, walkwork

\section{Yazışma Adresi (Address for Correspondence)}

\section{Dr. Hülya ŞAHIN}

Dr. Suat Seren Göğüs Hastalıkları ve Cerrahisi Eğitim ve Araştırma Hastanesi, Pulmoner Rehabilitasyon Kliniği, IZMIR - TURKEY

e-mail: drhdogan@yahoo.com 


\section{ÖZET}

\section{Obezitenin $K O A H^{\prime} l ı$ hastalarda dispne, egzersiz kapasitesi, yürüme işi ve iş yükü üzerine etkisi}

Giriş: Kronik obstrüktif akciğer hastalığı $(K O A H)$ ve obezite tüm dünyada mortalite ve morbiditeye neden olan önemli birer halk sağlığı sorunudur. KOAH ve obezite birlikteliğinin önümüzdeki yıllarda daha da artacağı tahmin edilmektedir. Obezite öncelikle solunum fonksiyonlarını, egzersiz kapasitesini, akciğer gazı değişimini ve solunum kaslarının dayanıkııı̆ını ve gücünü değiştirerek pulmoner sistemi etkiler. Bu çalışmada obez KOAH'lı hastalardaki dispne algısı, egzersiz kapasitesi, yürüme işi ve iş yükü değerlerini preobez ve normal kilolu KOAH'lı hastalara göre karşılaştırmayı amaçladık.

Materyal ve Metod: Çalışmaya 218 KOAH'lı hasta dahil edildi. Hastaları vücut kitle indeksi (VKi) hesaplandı, Dünya Sağlık Örgütü (DSÖ) kriterlerine göre normal kilolu $\left(V K i=18.5-24.9 \mathrm{~kg} / \mathrm{m}^{2}\right)$, pre-obez $\left(V K i=25-29.9 \mathrm{~kg} / \mathrm{m}^{2}\right)$ ve obez $\left(V K \dot{I}=30-39.9 \mathrm{~kg} / \mathrm{m}^{2}\right) \mathrm{olmak}$ üzere gruplandırıldı. Bütün hastalara solunum fonksiyon testleri ve arteryel kan gazı analizi yapıldı.Hastaların dispne algısını değerlendirmek için mMRC dispne skalası kullanıldı. Hastaların egzersiz kapasiteleri 6 dakika yürüme testi ile belirlendi. Yürüme işi ve iş yükü, yürüme mesafesine göre hesaplandı. Elde edilen değerler üç grup arasında karşılaştırıldı.

. Bulgular: KOAH'ı hastaların 72'si normal kilolu, 80'i pre-obez ve 66'sı obezdi. KOAH'ı obez hastaların solunum fonksiyon testlerinde FEV ${ }_{1}$ /FVC oranı ve TLCO değeri anlamlı derecede yüksek, VC değeri ise anlamlı derecede düşük bulundu $(p=0.001, p<0.001, p=0.01)$. Arteryel kan gazı değerlerinden; parsiyel karbondioksit basıncı obez KOAH'lılarda diğer hastalara göre anlamlı derecede yüksek bulundu ( $p=0.001$ ). Dispne algılarıve yürüme mesafeleri ise gruplar arasında anlamlı farklılık göstermiyordu. Yürüme işi ve iş yükü obez KOAH'lı hastalarda anlamlı olarak daha yüksekti $(p<0.001, p=0.005)$.

Sonuç: Obezite, KOAH'lı hastaların kan gazında ve solunum fonksiyon testlerinde kısmi değişimlere neden olur. Aynı zamanda yürüme işini ve iş yükünü artırır. Tüm bu değişimlere rağmen dispne algısı ve egzersiz kapasitesi üzerinde olumsuz etkiye sahip değildir.

Anahtar kelimeler: Obesite, KOAH, egzersiz kapasitesi, yürüme işi, iş yükü

\section{INTRODUCTION}

Obesity constitute a major public health problem with an increasing prevalence despite all preventive efforts and controls, and their prevalence is expected to further grow in the upcoming years $(1,2)$. Obesity is associated with a broad range of chronic diseases including hypertension, dyslipidemia, diabetes, and cardiovascular disease, and increases mortality (3). Although it influences many systems, obesity primarily affects the pulmonary system by altering respiratory functions, exercise capacity, pulmonary gas exchange, and endurance and power of respiratory muscles (4). Obesity is known to cause dyspnea, especially during exercise even in the absence of any respiratory diseases. Nevertheless, the effects of pathophysiological changes in respiratory functions and respiratory symptoms (particularly dyspnea) on the exercise performance have not yet been fully determined (5).

COPD is a global medical threat with a major impact on morbidity, mortality, and utilization of health care services $(6,7)$. It manifests with a series of pathophysiological changes and a broad range of clinical situations. Therefore, apart from the airway obstruction, it requires an evaluation considering different aspects such as symptoms, attacks, and comorbidities. COPD is often accompanied by major eating disorders (8). The current obesity outbreak has also changed the nature of eating disorders observed in patients with COPD. The majority of patients with COPD are overweight and obese instead of normal and low weight (6). It is estimated that the association of COPD and obesity will further grow in the future (9). While obesity triggers a restrictive-type disorder, COPD cases accompanied by obesity present both restrictive- and obstructive-type disorders. Therefore, it is difficult to evaluate and treat respiratory symptoms in obese patients with COPD (10).

In this present study, we aim to compare normalweight COPD patients with obese and pre-obese COPD patients with respect to respiratory functions, arterial blood gases analysis, perceived dyspnea, and exercise capacities.

\section{MATERIALS and METHODS}

The present study included 218 patients with COPD, referred to the pulmonary rehabilitation polyclinic at a Chest Diseases Training and Research Hospital from January 2013 to May 2016. Patients' demographic and clinical characteristics were recorded. We informed all participants of the purpose and evaluation methods of the study and received their consent. We recorded physical and demographic characteristics and smoking histories of the cases. They were questioned in detail regarding any comorbidity. We separately evaluated diabetes mellitus (DM), hipertansion (HT), and coronary artery disease (CAD) and examined goiter, 
sleep apnea syndrome, pulmonary embolism, osteoporosis, gastroesophageal reflux etc. under the category of other comorbidities. We performed respiratory and cardiac system examinations and pulmonary function tests (PFT) for all cases. Their chest radiography images and arterial blood gases (ABG) analysis were evaluated. Cases also underwent a 6 -minute walking test (6mWT).

\section{Respiratory Functions}

Body plethysmograph (Zan 500, Germany) and carbon monoxide (CO) diffusion capacity (Zan 300, Germany) were measured and assessed.

\section{Assessment of Dyspnea}

We relied on "Modified Medical Research Council" (mMRC) dyspnea scale to determine the severity of dyspnea experienced by the patients (11). ' 0 ' and ' 5 ' indicated lowest and highest levels, respectively. Patients were divided under three categories: "mild" (score: 1), "moderate" (score: 2-3), and "severe" dyspnea (score: 5) (12).

\section{Exercise Capacity}

Patients completed a $6 \mathrm{mWT}$ that measures the distance covered at maximum speed in a 6-min walk (13). We recorded their heart rate and oxygen saturation level before and after the test. Then, we multiplied the distance covered during the $6 \mathrm{mWT}$ with body weight to calculate the walkwork (14). Workload $=103.217+$ $(30.500 \times$ Gender $)+(-1.613 \times$ Age $)+[(0.002 \times$ (Distance $x$ weight)]. Female $=0$, Male $=1$. This was the formula to calculate the workload (15).

\section{COPD Severity}

The patients were divided into four groups based on GOLD criteria (16).

\section{BMI Classification}

According to the WHO criteria for body mass index $(\mathrm{BMI})$, the patients were classified as normal-weight $\left(\mathrm{BMl}=18.5-24.9 \mathrm{~kg} / \mathrm{m}^{2}\right)$, pre-obese $(\mathrm{BMl}=25-29.9 \mathrm{~kg} /$ $\left.\mathrm{m}^{2}\right)$ and obese $\left(\mathrm{BMl}=30-39.9 \mathrm{~kg} / \mathrm{m}^{2}\right)(17)$.

\section{Statistical Analysis}

We performed a Kruskal-Wallis Test to check the normality distribution of numeric variables. Categorical variables were described by frequencies and percentages, numeric variables were described by means and standard deviations or medians and interquartile ranges. The relationship between categorical variables was analyzed by a Chi-square
Test. One way ANOVA Test was used to compare normally distributed independent mean values of the following post-hoc Tukey Test. Non-parametric KruskalWallis Test was performed to compare independent medians with a post-hoc Dunn's Test. A p value less than .05 was accepted to indicate a statistically significant difference.

\section{RESULTS}

A total number of 218 patients with COPD were included in the study, consisting of 72 normal-weight, 80 pre-obese, and 66 obese patients. The age distribution was found homogeneous between the groups $(p=$ 0.936). There were 6 normal-weight, 8 pre-obese and 9 obese female patients with COPD, 23 in total. The gender distribution followed a similar pattern in all three groups ( $p=0.587$ ). The groups did not differ in terms of smoking $(p=0.379)$. The groups presented no difference as to the number of attacks $(p=0.541)$. The obese patients were hospitalized more than the pre-obese $(p=$ $0.034)$, whereas there was no difference between obese/normal-weight and pre-obese/normal-weight patients ( $p>0.05$ ). The obese patients exhibited a higher frequency of comorbidity than both normal-weight and pre-obese patients $(p=0.002)$, and no difference was found between the normal-weight and the pre-obese ( $p>0.05)$. The obese patients displayed a higher frequency of DM than both normal-weight and preobese patients $(p<0.001)$, while there was no difference between the normal-weight and the pre-obese $(p>$ $0.05)$. The HT frequency was higher among the obese than the normal-weight $(p=0.002)$, and no difference was found between the obese/pre-obese and pre-obese/ normal-weight patients. The prevalence of CAD and other comorbidities was similar in all groups $(p=0.982)$. Groups presented no difference when distributed based on GOLD staging $(p=0.146)$ (Table 1$)$. There was no difference between the groups in terms of dyspnea with respect to the MRC scale $(p=0.541)$ (Figure 1).

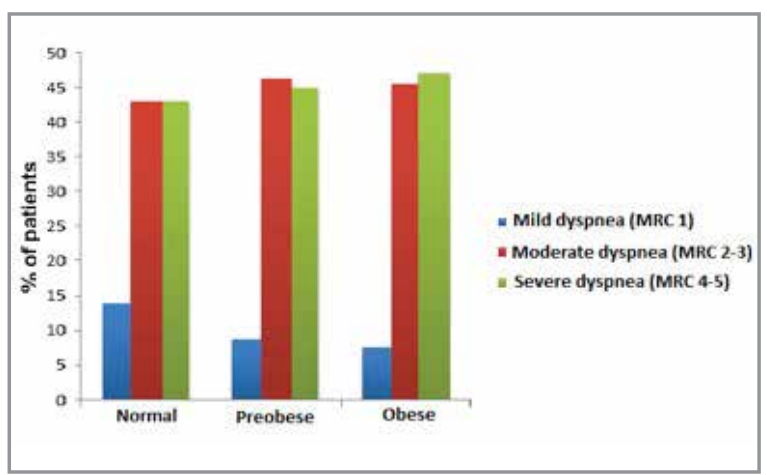

Figure 1. Dyspnea perceptionsby BMI category. 


\begin{tabular}{|c|c|c|c|c|}
\hline Variable & $\begin{array}{c}\text { Normal } \\
n=72\end{array}$ & $\begin{array}{c}\text { Pre-obese } \\
\mathbf{n}=\mathbf{8 0}\end{array}$ & $\begin{array}{l}\text { Obese } \\
n=66\end{array}$ & $\mathbf{p}$ \\
\hline Age (years) & $62.5 \pm 9.8$ & $63.1 \pm 9.5$ & $62.6 \pm 9$ & 0.936 \\
\hline Male gender & $66 / 72$ & $72 / 80$ & $57 / 66$ & 0.587 \\
\hline $\operatorname{BMI}\left(\mathrm{kg} / \mathrm{m}^{2}\right)$ & $23(2)$ & $27(2.75)$ & $32(3.25)$ & $<0.001$ \\
\hline Smoking (p/years) & $60(51.25)$ & $50(60)$ & $50(46.25)$ & 0.379 \\
\hline Number of exacerbation & $1(4)$ & $1(3)$ & $1(3)$ & 0.541 \\
\hline Number of hospitalization & $0(1)$ & $0(0)$ & $0(1)$ & 0.034 \\
\hline Comorbidity n,(\%) & $31(43.1)$ & $43(53.8)$ & $48(72.7)$ & 0.002 \\
\hline DM n (\%) & $2(2.8)$ & $8(10)$ & $17(25.8)$ & $<0.001$ \\
\hline HBP n (\%) & $12(16.7)$ & $24(30)$ & $29(43.9)$ & 0.002 \\
\hline CAD n $(\%)$ & $7(9.7)$ & $8(10)$ & $6(9.1)$ & 0.982 \\
\hline Other comorbidities n (\%) & $17(23.6)$ & $15(18.8)$ & $14(21.2)$ & $0.764)$ \\
\hline \multicolumn{5}{|l|}{ GOLD Stage n ( \%) } \\
\hline 1 & $2(2.8)$ & $1(1.3)$ & $3(4.5)$ & \multirow{4}{*}{0.146} \\
\hline 2 & $14(19.4)$ & $27(33.8)$ & $13(19.7)$ & \\
\hline 3 & $32(44.4)$ & $38(47.5)$ & 32 (48.5) & \\
\hline 4 & $24(33.3)$ & $14(17.5)$ & $18(27.3)$ & \\
\hline
\end{tabular}

The three groups had similar medians and mean FVC values $(p=0.097, p=0.115)$. $F_{1} V_{1} / F V C$ median was detected to be significantly lower among the normalweight patients compared to the pre-obese and obese $(p<0.001)$, while there was no difference between the pre-obese and obese patients. The median VC was lower in the obese than the normal-weight and preobese patients $(p=0.003)$ with no difference between the normal-weight and pre-obese cases ( $p>0.05)$. TLC and RV/TLC median values were not different among the three groups $(p=0.108,0.263)$. Median TLCO value was found to be significantly lower among the normal-weight patients than the pre-obese and obese $(p<0.001)$, while there was no difference between the pre-obese and obese patients ( $p>0.05$ ) (Table 2). Regarding median IC values, although normal/preobese patients and pre-obese/obese patients displayed similar figures, they were higher in the obese compared to the normal-weight patients $(p=0.006)$. RV and REV median values were similar among the normal-weight/ pre-obese and pre-obese/obese patients; however, they were significantly lower in the obese than

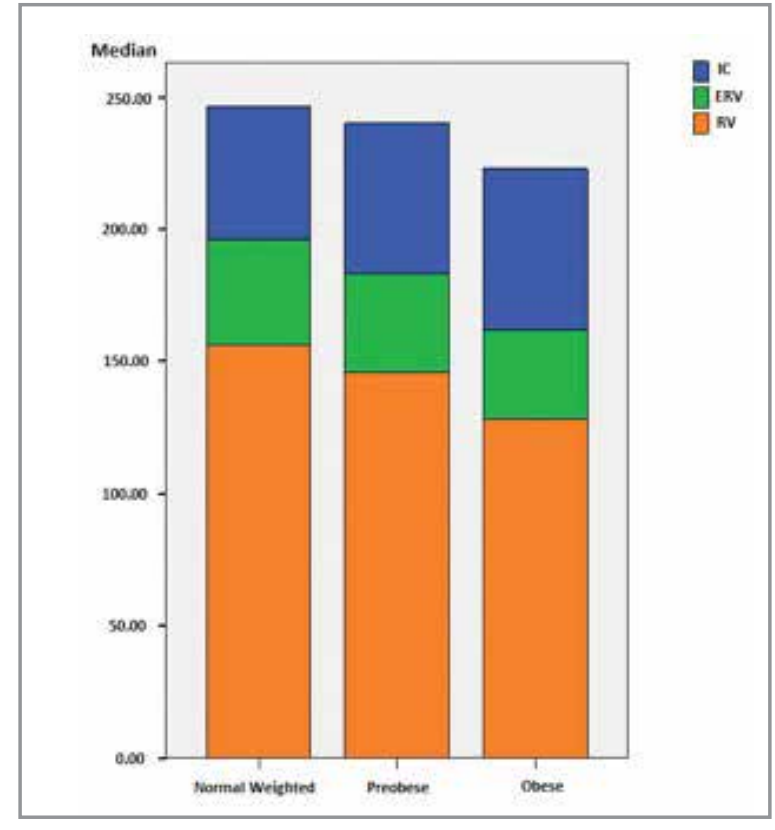

Figure 2. Static lung volumes by BMI category. 
The effect of obesity on dyspnea, exercise capacity, walk work and workload in patients with COPD

Table 2. Pulmonary function tests by BMI category

\begin{tabular}{|c|c|c|c|c|}
\hline Variable & $\begin{array}{c}\text { Normal } \\
n=72\end{array}$ & $\begin{array}{c}\text { Preobese } \\
n=80\end{array}$ & $\begin{array}{l}\text { Obese } \\
n=66\end{array}$ & $\mathbf{p}$ \\
\hline $\mathrm{FEV}_{1}(\%)$ & $40(27.48)$ & $46(33.57)$ & $40(30.53)$ & 0.097 \\
\hline FVC (\%) & $62(43.72)$ & $63(49.72)$ & $54(42.69)$ & 0.115 \\
\hline $\mathrm{FEV}_{1} / \mathrm{FVC}$ & $52(45.61)$ & $57(52.66)$ & $60(54.70)$ & $<0.001$ \\
\hline VC & $66(49.81)$ & 67 (55.79) & $57(47.70)$ & 0.010 \\
\hline IC & $50(36.70)$ & 55 (38.74) & $62(49.74)$ & 0.022 \\
\hline TLC & $101(84.117)$ & $101(82.115)$ & $93(77.102)$ & 0.108 \\
\hline RV & $158(115.206)$ & $146(108.173)$ & $129(94.171)$ & 0.007 \\
\hline ERV & $39(22.80)$ & 35 (15.67) & $34(10.54)$ & 0.030 \\
\hline RV/TLC & $160(135.182)$ & $153(122.170)$ & $153(135.175)$ & 0.263 \\
\hline DLCO & $27(17.38)$ & 37 (24.47) & $42(28.54)$ & $<0.001$ \\
\hline
\end{tabular}

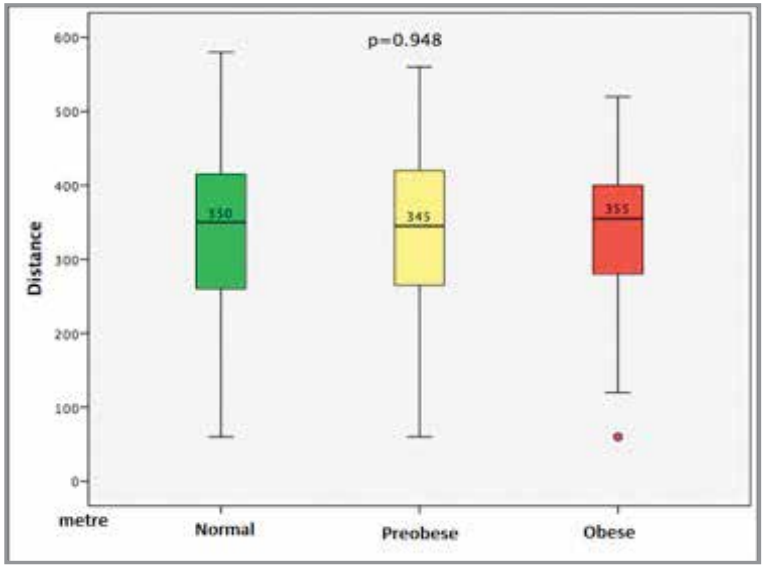

Figure 3. Six minute walk distance by BMI category.

normal-weight patients $(p=0.002, p=0.014)$ (Figure 2).

An examination of arterial blood gases showed similar median values for $\mathrm{PaO}_{2}, \mathrm{pH}$ and $\mathrm{O}_{2}$ saturation for three groups. The $\mathrm{PaCO}_{2}$ median was significantly higher in the obese group than the remaining two $(p=$ 0.001 ), and it was similar for the normal-weight and pre-obese patients (Table 3). 6-min walking distance median values were similar for the three groups $(p=$ 0.948) (Figure 3).

Every group had a significantly different workload mean $(p=0.005)$. The post-hoc analysis revealed that this was due to the significantly higher workload mean

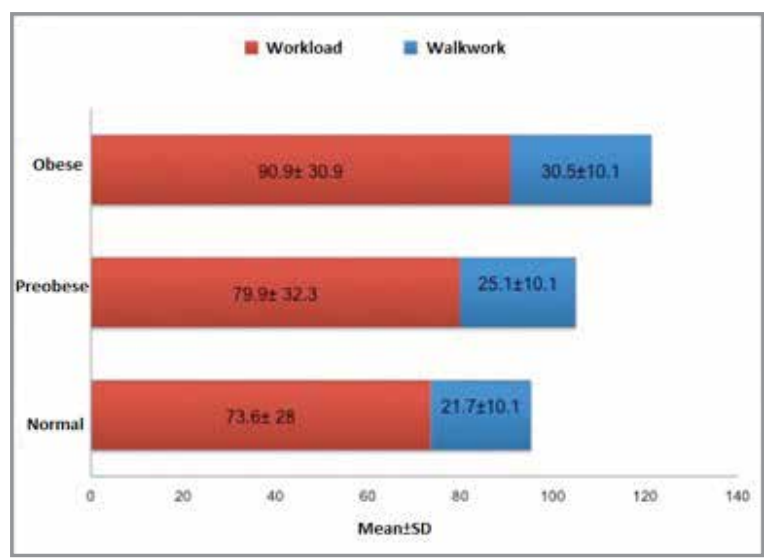

Figure 4. Workload and walkwork values by BMI category.

exhibited by the obese in comparison to that of the normal-weight patients $(p<0.001)$. No significant difference was detected between the mean workload of normal-weight and pre-obese patients or that of overweight and obese patients. Every group had a significantly different mean walkwork $(p=0.001)$. The post-hoc analysis indicated that this difference was associated with the significantly higher mean walkwork exhibited by the obese in comparison to that of the pre-obese and normal-weight patients $(p<0.001, p<$ 0.001 ). The mean walkwork values of normal-weight and pre-obese patients presented no significant difference ( $p>0.05)$ (Figure 4). 
Table 3. Arterial blood gases by BMI category

\begin{tabular}{|c|c|c|c|c|}
\hline Variable & $\begin{array}{c}\text { Normal } \\
n=72\end{array}$ & $\begin{array}{c}\text { Preobese } \\
\mathbf{n}=\mathbf{8 2}\end{array}$ & $\begin{array}{l}\text { Obese } \\
n=66\end{array}$ & p \\
\hline $\mathrm{PaO}_{2}$ (median, IQR) & $73.5(14.25)$ & 71 (18) & $70(16)$ & 0.411 \\
\hline $\mathrm{PaCO}_{2}$ (median, IQR) & $39.5(8.02)$ & $40(5)$ & $44(9.5)$ & 0.001 \\
\hline pH (median, IQR) & $7.42(0.04)$ & $7.41(0.04)$ & $7.4(0.03)$ & 0.088 \\
\hline $\mathrm{SaO}_{2}$ (median, IQR) & $95(3)$ & $94.7(3)$ & $94(4)$ & 0.453 \\
\hline
\end{tabular}

\section{DISCUSSION}

In the context of the present study, obese COPD patients were found to be hospitalized significantly more than the other two categories, namely the overweight and pre-obese patients. The obese group presented a higher prevalence of comorbidity, and the prevalence of DM and HT was higher in this group, except the coronary artery disease. A detailed examination of PFT revealed a significantly lower $\mathrm{FEV}_{1} / \mathrm{FVC}$ ratio and TLCO value for the normal-weight patients across the three groups. VC, RV, and ERV values were significantly lower in the obese group, whereas the IC was significantly higher. Analysis of arterial blood gas parameters, the partial carbon dioxide pressure was significantly higher among the obese patients. Perceived dyspnea was similar for all three groups. Although the 6-min walking distance was similar for all the groups, the obese group presented a significantly higher mean workload and walkwork figures. On the other hand, the groups did not exhibit a significant difference in terms of age, gender, smoking quantity or GOLD staging.

COPD is accompanied by obesity more often than not, and this combination is a chronic medical condition with a growing prevalence on a global scale (18). Although the relationship between COPD and obesity has not been fully revealed, obesity might be associated with the systemic inflammation including the pro-inflammatory cytokines in the case of COPD (3). In obesity, the adipose tissue accumulated within the thoracic cage, diaphragm and stomach is defined as a major source of pro-inflammatory cytokines (e.g. interleukin6) stimulating the synthesis of C-reactive protein $(4,19)$.

Obesity is associated with a broad range of comorbidities including hypertension, type-2 diabetes and cardiovascular diseases, and it is an independent risk factor for reduced survival $(3,20,21)$. Alongside the coronary artery disease, hypertension and DM were observed at a higher rate among the obese patients as part of the present study as well. Similar to the study which reported an association between comorbidity and increased hospitalization risk, we also found that obese patients exhibited significantly higher hospitalization rates (22).

Unless morbid obesity develops, obesity usually does not reduce $\mathrm{FEV}_{1}$ or FVC values, and the $\mathrm{FEV}_{1} / \mathrm{FVC}$ ratio is maintained (23). However, a study demonstrated higher $\mathrm{FEV}_{1}$ values on the part of overweight and obese patients with COPD compared to the normalweight cases (12). Again, whereas another study found lower $\mathrm{FEV}_{1}$ values for normal-weight patients than overweight and obese cases, FVC values did not differ significantly across three groups, and $\mathrm{FEV}_{1} / \mathrm{FVC}$ ratio was found to be higher among overweight and obese patients (24). A study that examined patients under four BMI-based categories, namely thin, normalweight, overweight and obese groups, detected a significantly higher $\mathrm{FEV}_{1} / \mathrm{FVC}$ ratio in obese patients (25). In the present study, however, FEV 1 and FVC values did not differ significantly, whereas the $\mathrm{FEV}_{1} /$ FVC ratio was significantly lower in normal-weight patients than the other two groups.

The fat tissue accumulating in obese patients applies pressure to the chest wall, diaphragm and lungs, which results in diaphragm misplacement and reduced static lung volumes $(4,5,26)$. A study conducted on normal-weight and obese patients found significantly lower TLC and FRC values for obese patients, while the RV value did not present a significant difference (27). In another study, COPD patients were examined in three groups, namely normal-weight, overweight, and obese; normal-weight group exhibited higher RV 
and TLC values, whereas IC values did not differ significantly (24). A study divided patients into five groups, namely normal-weight, overweight, and mildmoderate-morbid obese and detected a linear regression between $B M I$ and $V C, T L C$, and $R V$ values (28). As part of the present study, we observed no significant difference between TLC and RV/TLC, while RV and ERV were found significantly lower in the obese group. We also detected a low VC in the same group, which was similar to the findings of the mentioned study (27). IC and IC/TLC ratio (for TLC is maintained) rise as BMI increases (20). In line with reports in the relevant literature, those studies and our study observed a significantly high IC value in obese patients $(25,29)$. Similar to the findings of other studies we found significantly high TLCO values in obese patients (27-29). This finding might be associated with increased pulmonary blood volume $(9,23)$.

The ventilation/perfusion ratio loses balance due to the microatalectasia occurring in the basal lungs, which adversely affects the gas exchange, and oxygenation deteriorates. Partial oxygen pressure may slightly decrease, while carbon dioxide pressure increases borderline $(5,9,23)$. As part of a study that examined two groups of patients with COPD, namely normalweight and overweight/obese groups, no significant difference was found in terms of partial oxygen and carbon dioxide pressures (6). We, however, observed a significantly higher partial carbon dioxide pressure in the obese group, despite the absence of a significant difference between the groups in terms of partial oxygen pressure and oxygen saturation.

Although some consider obesity to trigger dyspnea, there is limited evidence to support this claim (24). Obese individuals exhibit a reduced tidal volume; however, respiration increases and their minute ventilation is higher than normal-weight individuals (5). Increased respiratory workload and reduced static pulmonary volumes may trigger dyspnea in obese patients (26). Grading dyspnea severity with respect to the MRC scale, a study found that $2+$ scores were significantly more frequent in the obese group, whereas there was no significant difference across normal-weight, overweight, and obese patient groups when the patients were grouped based on mildmoderate-severe dyspnea (12). Another study that compared normal-weight and obese patients also reported that dyspnea severity did not increase in obese patients (29). One study grouped patients by dyspnea severity, categorizing mild-moderate dyspnea cases under group 1 and severe dyspnea cases under group 2, and it observed no significant difference between the two groups in terms of BMI values (26). We also determined a homogeneously distributed dyspnea severity across three groups, with no difference between them.

Obese patients with COPD are expected to experience worsened dyspnea and exercise intolerance due to increased metabolic requirements and body mass (29). Some studies have reported significantly lower distance figures for obese patients $(8,24,30)$. However, as is the case in the study that found no significant difference between normal-weight and obese patients in terms of exercise performance, all three groups exhibited a similar distribution of 6-min walking distance as part of the present study (29). This might be associated with the similar distribution of dyspnea severity across three groups. In obese patients, the relative decrease in the dynamic hyperinflation triggered by COPD might have prevented increased exercise intolerance despite increased respiratory and metabolic requirements.

Walkwork depends on and changes with body weight. Some argue that walkwork better reflects the functional capacity than the 6-min walking distance (14). There are studies reporting a significantly higher walkwork in obese patients with COPD, despite their low exercise performance $(8,24)$. We also found a significantly higher walkwork in obese patients with COPD.

In obese patients, weight-based exercises such as cycling ergometer cost a great deal of metabolic effort. Therefore, the obese patients exhibit a significantly increased amount of energy consumed by workload per unit in the context of cycling ergometer (5). We also found a significantly higher mean workload in obese patients as part of the present study.

In conclusion, obese patients with COPD presented a high $\mathrm{FEV}_{1} / \mathrm{FVC}$ ratio in respiratory function tests, low VC, RV and ERV, increased IC and TLCO, and high partial carbon dioxide pressure. Moreover, we observed no increase in perceived dyspnea despite increased workload in obese patients. Their exercise performance did not decrease but functional capacities increased. To sum up, in the context of COPD, obesity does not have an adverse effect on perceived dyspnea or exercise capacity, although it triggers partial changes in blood gas and respiratory function test. 


\section{REFERENCES}

1. Franssen FM. Overweight and obesity are risk factors for COPD misdiagnosis and overtreatment. Chest 2014; 146:1426-8.

2. Hanson C, Rutten EP, Wouters EFM, Rennard S. Influence of diet and obesity on COPD development and outcomes. International Journal of COPD 2014;9:723-33.

3. Guenette JA, Jensen $D, O^{\prime}$ Donnell DE. Respiratory function and the obesity paradox. Curr Opin Clin Nutr Metab Care 2010;13:618-24.

4. Faria AG, Ribeiro MA, Marson FA, Schivinski Cl, Severino $S D$, Ribeiro JD, et al. Effect of exercise test on pulmonary function of obese adolescents. J Pediatr 2014;90:242-9.

5. Dreher $M$, Kabitz HJ. Impact of obesity on exercise performance and pulmonary rehabilitation. Respirology 2012;17:899-907

6. Galesanu RG, Bernard S, Marquis K, Lacasse Y, Poirier $P$, Bourbeau J, et al. Obesity in chronic obstructive pulmonary disease: is fatter really better? Can Respir J 2014;21:297-301.

7. Greening NJ, Evans RA, Williams JE, Green RH, Singh SJ, Steiner MC. Does body mass index influence the outcomes of a Waking-based pulmonary rehabilitation programme in COPD? Chron Respir Dis 2012;9:99-106.

8. 8.García-Rio F, Soriano JB, Miravitlles M, Muñoz L, DuranTauleria E, Sánchez G, et al. Impact of obesity on the clinical profile of a population-based sample with chronic obstructive pulmonary disease. PLoS One 2014;9:e105220.

9. O'Donnell DE, Ciavaglia CE, Neder JA. When Obesity and Chronic Obstructive Pulmonary Disease Collide. Physiological and Clinical Consequences. Ann Am Thorac Soc 2014;11: 635-44.

10. Zutler M, Singer JP, Omachi TA, Eisner M, Iribarren C, Katz $P$, et al. Relationship of obesity with respiratory symptoms and decreased functional capacity in adults without established COPD. Prim Care Respir J 2012;21:194-201.

11. Spruit M, Singh S, Garvey C, ZuWallack R, Nici L, Rochester $C$, et al. An Official American Thoracic Society/European Respiratory Society Statement: Key Concepts and Advances in Pulmonary Rehabilitation. Am J Respir Crit Care Med 2013;188:13-64.

12. Cecere $L M$, Littman Al, Slatore CG, Udris EM, Bryson CL, Boyko EJ, et al. Obesity and COPD: associated symptoms, health-related quality of life, and medication use. COPD 2011;8:275-84.

13. ATS statement: guidelines for the six-minute walk test. Am J Respir Care Med 2002;166:111-7.

14. Carter R, Holiday DB, Nwasuruba C, Stocks J, Grothues C, Tiep B. 6-minute walk work for assessment of functional capacity in patients with COPD. Chest 2003;123:1408-15.

15. Luxton N, Alison JA, Wu J, Mackey MG. Relationship between field walking test and incremental cycle ergometry in COPD. Respirology 2008; 13:856-62.
16. GOLD executive committee. Global strategy for diagnosis, management and preventionof COPD, [updated 2009; accessed 2010 July 1]. Avaliable from: http://www.golcopd. com.

17. WHO BMI Classification. Available from: http://apps.who. int/bmi/index.jsp?introPage $=$ intro- $3 . h t m l$.

18. Franssen FME, O'Donnell DE, Goossens GH, Blaak EE, Schols AMWJ. Obesity and the lung: 5. Obesity and COPD. Thorax 2008;63:1110-7.

19. Blum A, Simsolo C, Sirchan R, Haiek S. "Obesity paradox" in chronic obstructive pulmonary disease. Isr Med Assoc J 2011;13:672-5.

20. O'Donnell DE, O'Donnell CD, Webb KA, Guenette JA. Respiratory Consequences of Mild-to-Moderate Obesity: Impact on Exercise Performance in Health and in Chronic Obstructive Pulmonary Disease. Pulm Med 2012;2012:818925.

21. Poulain $M$, Doucet $M$, Major GC, Drapeau V, Sériès $F$, Boulet $L P$, et al. The effect of obesity on chronic respiratory diseases: pathophysiology and therapeutic strategies.CMA J 2006; 174:1293-9.

22. Franssen FM, Rochester CL. Comorbidities in patients with COPD and pulmonary rehabilitation: do they matter? Eur Respir Rev 2014;23:131-41.

23. Littleton SW. Impact of obesity on respiratory function. Respirology 2012;17:43-9.

24. Sava F, Laviolette L, Bernard S, Breton MJ, Bourbeau J, Maltais $F$. The impact of obesity on walking and cycling performance and response to pulmonary rehabilitation in COPD. BMC Pulm Med 2010;10:55.

25. O'Donnell DE, Deesomchok A, Lam YM, Guenette $J A$ Amornputtisathaporn N, Forkert $L$, et al. Effects of BMI on static lung volumes in patients with airway obstruction. Chest 2011;140:461-8.

26. El-Gamal H, Khayat A, Shikora S, Unterborn JN. Relationship of dyspnea to respiratory drive and pulmonary function tests in obese patients before and after weight loss. Chest 2005; 128:3870-4.

27. Aiello M, Teopompi E, Tzani P, Ramponi S, Gioia MR, Marangio $E$, et al. Maximal exercise in obese patients with COPD: the role of fat free mass. BMC Pulm Med 2014;14:96.

28. Jones RL, Nzekwu MM. The effects of body mass index on lung volumes. Chest 2006; 130:827-33.

29. Ora J, Laveneziana P, Ofir D, Deesomchok A, Webb KA, O'Donnell DE. Combined effects of obesity and chronic obstructive pulmonary disease on dyspnea and exercise tolerance. Am J Respir Crit Care Med 2009;180:964-71.

30. Ramachandran K, McCusker C, Connors M, Zuwallack R, Lahiri B. The influence of obesity on pulmonary rehabilitation outcomes in patients with COPD. Chron Respir Dis 2008;5:205-9. 